\title{
EVALUASI TEMPLATE MATCHING PADA PELACAKANMARKERLESS TERHADAP KEMAMPUAN PERANGKAT SMARTPHONE
}

\author{
Yudi Setiawan $^{1}$, Kurnia Anggriani ${ }^{2}$, Boko Susilo ${ }^{3}$ \\ 1,2,3 Program Studi Teknik Infomatika, Fakultas Teknik, Universitas Bengkulu. \\ Jl. WR. Supratman Kandang Limun Bengkulu 38371A INDONESIA \\ (telp: 0736-341022; fax: 0736-341022) \\ ${ }^{1}$ ys.teknik@gmail.com \\ ${ }^{2}$ kurniaanggriani@gmail.com \\ 3bksusilo@gmail.com
}

Abstrak: Penelitian ini membahas perancangan aplikasi Augmented Reality (AR) untuk melakukan pelacakan markerless dengan mengimplementasikan metode template matching. Penelitian ini dilakukan bertujuan untuk mengevaluasi metode template matching dengan membandingkan tingkat kemampuan perangkat smartphone dalam pelacakan markerless AR. Evaluasi metode template matching berupa identifikasi jarak jangkau markerless dari kamera smartphone, sudut jangkauan markerless terhadap kamera, dan luas area tangkapan markerless yang dapat dikenali oleh aplikasi AR. Ketiga identifikasi markerless tersebut kemudian dibandingkan dengan kecepatan processor, read only memory (RAM), dan besar pixel kamera dari berbagai smartphone yang berbeda-beda. Aplikasi Augmented Reality ini dirancang dengan menggunakan SDK Vuforia.Markerless yang dirancang berupa objek-objek smartphone. Hasil dari penelitian ini berupa evaluasi dari implementasi metode template matching dalam pengenalan markerless Augmented Reality, kesesuaian objek sebenarnya dengan informasi virtual yang diberikan (correctness), dan pengklasifikasian kemampuan pengenalan markerless terhadap kemampuan perangkat smartphone.

Kata kunci: Augmented Reality, markerless,smartphone, SDK Vuforia.

\begin{abstract}
This study discusses the design of Augmented Reality (AR) application to triangulate Markerless by implementing template matching method. This research purpose to evaluate the template matching method by comparing the level of the tracking capabilities of smartphone in Markerless AR. Template matching method is evaluated by identificate the range of smartphone cameras, the angle range of the camera Markerless and Markerless catchment area that can be recognized by $A R$ applications. Third Markerless identification is then compared with the speed of the processor, read only memory (RAM), and a large pixel camera of a variety of different smartphone. Augmented Reality application is designed by using SDK Vuforia.Markerless designed in the form of objects smartphone. The results of this research is evaluation of the implementation of template matching methods in the introduction of Augmented Reality Markerless, conformity with the actual objects given virtual information (correctness), and classification capabilities Markerless introduction to the capabilities of smartphone devices.
\end{abstract}

Keywords: Augmented Reality, Markerless, smartphone, Vuforia SDK.

\section{PENDAHULUAN}

Salah satu teknik penting dari digital imagesprocessing adalah template matching. Template matching merupakan sebuah teknik yang digunakan dalam mengklasifikasikan sebuah objek dengan melakukan perbandingan bagian gambar dengan gambar lainnya[1]. Template matching digunakan secara luas untuk memproses sebuah gambar dan citra. Teknik ini digunakan di dalam aplikasi objek untuk pengalokasian, deteksi tepi objek, untuk memetakan rute untuk mobile robot dan pada teknik pendaftaran gambar.

Pada ilmu Computer Vision, konsep dari interest points disebut juga dengan titik kunci (keypoints) atau titik yang memiliki ciri khusus/khas (feature points). Sehingga secara umum, template matching merupakan metode yang sering digunakan dalam pengolahan citra 
pengenalan sebuah objek (object recognition).

Template matching memiliki beberapa metode pelacakan titik (points detectors), yaitu; Harris corners, fast feature, scale-invariant SURF features, dan SURF features[2].

Augmented reality merupakan synthesis perumpamaan nyata dan virtual [3]. Aplikasi augmented reality telah diterapkan di berbagai bidang kehidupan. Perkembangan smartphone telah mendukung pengembangan aplikasi ini. Augmented reality juga merupakan konsep aplikasi dari menggabungkan dunia fisik (objek sesungguhnya) dengan dunia digital, tanpa mengubah bentuk objek fisik tersebut. Pengenalan objek (teks dan gambar) yang dituju menampilkan berbagai informasi mengenai objek tersebut. Augmented reality sebagai sebuah sistem kognitif, hendaknya dapat memahami secara utuh persepsi dari pengguna[4].

Penanda objek pada Augmented Reality secara umum dikelompokkan menjadi marker dan markerless. Penggunaan penanda objek berupa marker terdiri dari; barcode, QR Code, dan printed $A R$ marker. Sedangkan penanda objek yang termasuk ke dalam markerless, yaitu; natural printed AR marker dan real life marker.Keuntungan utama dari sistem berbasis marker adalah bahwa penanda dapat dirancang sedemikian rupa untuk memastikan mereka tetap relatif baik terdeteksi oleh aplikasi Augmented Reality. Kerugian yang jelas dari penggunaan penanda berbasis marker adalah modifikasi/perubahan fisik marker dari sebuah adegan (scene) diperlukan selama proses penangkapan marker[5]. Untuk mengurangi ketergantungan terhadap perubahan marker, maka penelitian ini menggunakan markerless yang memiliki keuntungan perubahan secara natural dari sebuah sceneAR
Penelitian ini, objek markerless berupa smartphone. Objek smartphone digunakan karena smartphone memiliki bentuk umum yang sama, yaitu persegi empat atau oval. Akan tetapi, walaupun memiliki bentuk umum yang sama, beberapa smartphone memiliki ciri khas/keunikan masing-masing, hal ini yang akan digunakan dalam pengenalan pola smartphone menggunakan metode template matching.

Paper ini membahas tentang perancangan aplikasi Augmented Reality dengan menggunakan template matching sebagai metode pelacakan objek markerless. Penanda objek yang dirancang berupa smartphone sehingga terlebih dahulu akan dilakukan pendefinisian dari pola masing-masing smartphone. Kemudian penanda akan diujikan dengan beberapa smartphone yang memiliki spesifikasi yang berbeda-beda. Pengujian dilakukan berdasarkan jarak jangkauan pengenalan penanda, besar sudut jangkauan pengenalan penanda, dan luas tangkapan penanda yang dapat dikenali. Dari masing-masing pengujian akan dibandingkan terhadap kemampuan processor, read only memory, dan kamera dari masing-masing smartphone.

\section{LANDASAN TEORI}

\section{A. Augmented Reality}

Augmented reality merupakan konsep penggabungan dunia virtual ke dalam dunia nyata. Penciptaan dunia virtual dilakukan untuk membangkitkan persepsi user untuk memahami informasi dari objek yang dikenali. Augmented Reality didefinisikan sebagai penggunaan komputer digital real-time dan perangkat keras spesial lainnya dan perangkat lunak untuk menghasilkan sebuah simulasi dunia atau lingkungan alternative, yang dipercaya sebagai sesuatu yang nyata atau benar bagi user [6]. 


\section{B. Marker-based dan Markerless AR}

Terdapat dua metode pengenalan penanda pada augmented reality, yaitu; marker dan markerless. Marker merupakan penanda khusus yang dibuat seperti sebuah barcode atau bingkai hitam, sedangkan markerless merupakan penanda yang berhubungan dengan objek secara langsung. Adapun evolusi dari penggunaan marker hingga penggunaan objek nyata dalam pengenalan penanda augmented realityseperti ditunjukkan pada Gambar 1.

Evolusi penanda ditunjukkan dengan perubahan penanda yang dimulai dari bentuk barcode hingga bentuk nyata di kehidupan (real life). Penanda diklasifikasikan menjadi dua, yaitu; marker dan markerless. Evolusi penanda yang termasuk di dalam klasifikasi marker atau yang dikenal sebagai technical markers, yaitu; barcode, QR code, dan printed AR marker. Sedangkan yang termasuk kedalam markerless (natural markers), yaitu; natural printed AR marker dan real life marker.

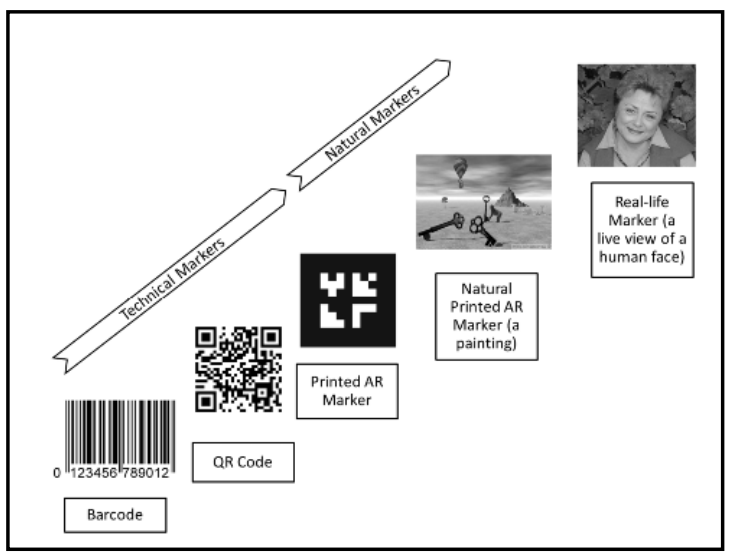

Gambar 1. Evolusi Marker

Penggunaan marker atau markerless memiliki keuntungan dan kekurangan masing-masing [7]. Adapun keuntungan dari penggunaan marker, yaitu:

1. Algoritma pendeteksian yang kecil.

2. Kuat dalam perubahan pencahayaan (stabil).
Adapun kekurangan dari penggunaan marker, yaitu;

1. Tidak berkerja padabagian yang tumpang tindih.

2. Gambar marker harus berupa hitam dan putih.

3. Memiliki bentuk persegi yang umum (untuk memudahkan pencarian)

4. Marker tidak memiliki keindahan estetika visual.

5. Tidak memiliki objek real dalam kehidupan sehari-hari.

Keuntungan dari markerless, yaitu:

1. Dapat digunakan untuk mendeteksi objek nyata (real-world).

2. Dapat bekerja meskipun target objek di dalam bagian tumpang tindih.

3. Dapat memiliki bentuk dan tekstur yang berubah-ubah (kecuali solid dan tekstur gradasi lembut)

\section{Template Matching}

Pelacakan titik-titik ciri khas sebuah gambar dengan menggunakan sudut-sudut yang terdapat pada gambar dapat menjadi solusi pencarian pola dari sebuah gambar. Pendeteksian sudut-sudut tersebut dipetakan untuk memudahkan perancangan pola gambar. Sudut-sudut tersebut menjadi menarik karena memiliki dua dimensi yang menjadi ciri yang secara akurat dapat di batasi setiap akurasi sub-pixel (sebagai persilangan dua sisi/edges)[2].

Template matching merupakan sebuah teknik yang digunakan dalam mengkelompokkan sekumpulan objek dengan melakukan perbandingan bagian gambar dengan gambar lainnya. Template matching digunakan secara luas untuk memproses sebuah gambar dan citra. Pemilihan pencocokan pola dilakukan secara saling bergantung pada sifat alami dari sebuah gambar 
atau objek [1]. Konsep metode pencocokan pola (template matching) dapat dilakukan dengan beberapa konsep pelacakan titik, yaitu; Harris corners, fast feature, scale-invariant SURF feature, dan SURF features.

Pada penelitian ini, pencocokan pola (template matching) menggunakan pelacakan titik Harris corners. Hal ini dilakukan dengan menentukan notasi sudut-sudut yang ada pada gambar/objek. Penentu notasi sudut-sudut gambar dilakukan dengan merata-ratakan nilai intensitas perubahan langsung di dalam jendal-jendela kecil sekitar titik perhatian yang diduga. Dengan mempertimbangkan sebuah perpindahan vector $(u, v)$, maka rerata perubahan intensitas gambar dirumuskan dalam persamaan;

$$
R=\sum\left(I(x+u, y+v)-I(x, y)^{2}\right)
$$

Persamaan (1) menjelaskan perubahan intensitas titik awal $(\mathrm{x}, \mathrm{y})$ dengan titik perbandingan (u,v) di sekitar titik dugaan awal, yang kemudian dari perubahan intensitas tersebut maka dapat ditentukan titik-titik yang khas sebagai ciri dari gambar tersebut. Sehingga akhir penyelesaian berupa pencarian pixel-pixel tetangga sekitar. Perubahan rerata intensitas dapat dikomputasi di dalam semua kemungkinan secara langsung, untuk mendefinisikan sudut sebagai titik yang mana perubahan rerata lebih tinggi dibandingkan di dalam satu arah [2].

\section{PEMBAHASAN}

\section{A. Perancangan Markerless}

Perancangan markerless $A R$ pada penelitian ini terdiri dari tiga proses perancangan, yaitu; proses pengambilan gambar, proses pelacakan pola gambar, dan proses manajemen database markerless AR. Markerless dirancang dengan menggunakan gambar dari sisi depan/muka smartphone. Proses pengambilan gambar menggunakan kamera digital untuk mendapatkan tekstur dari smartphone secara detail. Hasil dari pengambilan gambar sisi depan smartphone kemudian dilakukan proses cropping, menggunakan tool Adobe Photoshop Cs 6, hal ini bertujuan untuk menghilangkan background. Jika background memiliki teksture, maka teksture tersebut akan diperhitungkan sebagai pola nantinya. Adapun gambar sisi depan dari beberapa smartphone terdapat pada Gambar 2.

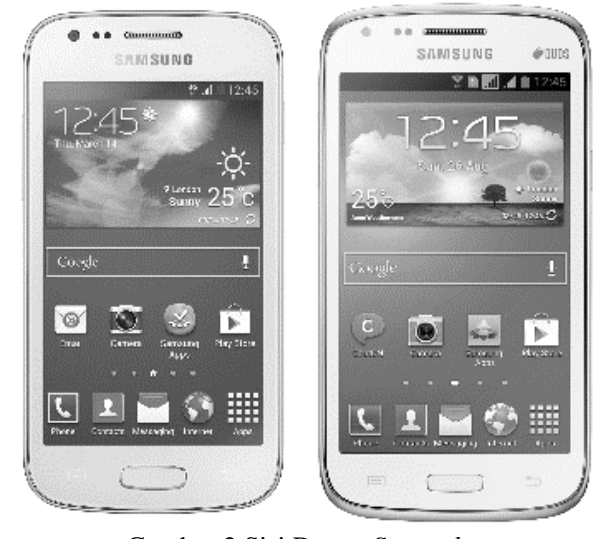

Gambar 2.Sisi Depan Smartphone

Gambar sisi depan smartphone yang didapatkan, kemudian dilanjutkan dengan proses pelacakan pola dari gambar tersebut. Proses pelacakan pola menggunakan metode Harris corners yang akan menghasilkan titik-titik yang merupakan sudut-sudut perubahan intesitas warna dari tektur gambar. Titik-titk kunci tersebut membentuk pola sebagai pembeda pola markerless satu dengan pola markerless lainnya. Proses pelacakan pola (template matching) dilakukan dengan cara objek-objek pada dunia nyata ditangkap oleh kamera smartphone, kemudian dilakukan pengidentifikasian pola dari objek-objek tersebut. Pola dari objek-objek tersebut kemudian akan dilakukan pencocokan dengan pola-pola objek yang telah disimpan di dalam database AR. Adapun gambar pola dari objek yang merupakan 
kumpulan dari titik-titik kunci dari beberapa smartphoneditunjukkan pada Gambar 3.

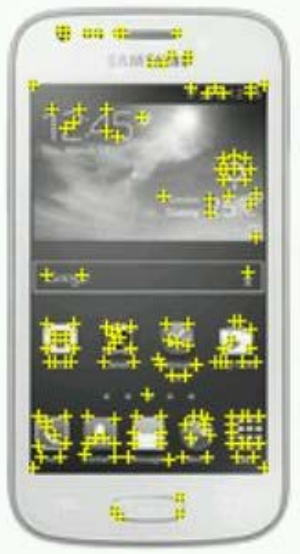

Gambar 3. Pola ObjekSmartphone

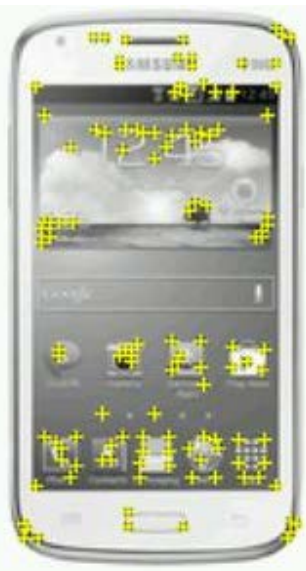

Penyimpanan informasi dari pola objek smartphone dilakukan pada manajemen database Android. Manajemen databasemarkerless AR disimpan di objek SharedPreferences dalam format *.xml. Penyimpanan pola objek berupa penyimpanan koordinat titik-titik kunci dari objek. Koordinat titik-titik kunci tersebut memiliki jarak setiap titik tersebut. Kumpulan titik-titik kunci tersbutlah yang akan membentuk pola sebagai identifikasi objek.

\section{B. Perancangan Aplikasi Augmented Reality}

Proses perancangan aplikasi Augmented Reality, aplikasi dirancang berbasis Android. Perancangan aplikasi menggunakan SDK Vuforia dengan IDE Eclipse sebagai editor peng-code-an. Proses compiling dilakukan dengan menggunakan tool NDK Android. Markerless yang telah dirancang disimpan sebagai objek pengenalan pola dan disimpan dalam format *.xml. Sedangkan perancangan informasi tambahan dirancang menggunakan aplikasi Google SketchUp. Adapun integrasi antar Augmented Reality Engines ditunjukkan pada Gambar 4.

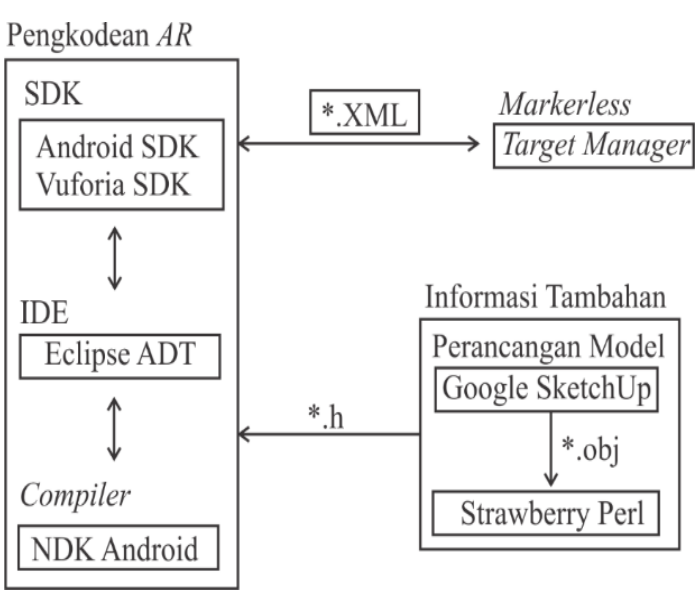

Gambar 4. Integrasi Antar Augmented Reality Engines

Gambar 4 menunjukkan integrasi antar AR Engines yang meliputi proses pengkodean AR, perancangan markerless, dan perancangan informasi tambahan dari markerless. Pada proses pengkodean AR meliputi penggunaan SDK (Android SDk dan Vuforia SDK), IDE Eclipse ADT, dan Compiler NDK Android. Markerless yang dirancang, terlebih dahulu dilakukan penentuan pola untuk proses pencocokan pola (template matching). Pola dari markerless kemudian disimpan didalam database AR dalam format (di-export) *.xml yang dapat dipanggil oleh Android SDK. Sedangkan untuk informasi tambahan dirancang menggunakan Google SketchUp dan dikonversi ke format header *.h dengan menggunakan Strawberry Perl.

Pada Gambar 5 menunjukkan alur kerja dari aplikasi Augmented Reality yang dirancang. Proses kerja dari aplikasi dilakukan dengan mengarah kamera smartphone ke objek yang sebagai markerless. Kemudian objek yang ditangkap dilakukan proses pelacakan pola. Pola objek yang didapatkan dilakukan seleksi dengan pola yang telah disimpan pada database, kemudian jika terdapat kecocokan maka akan menampilkan informasi tambahan berdasarkan nama markerless tersebut. 


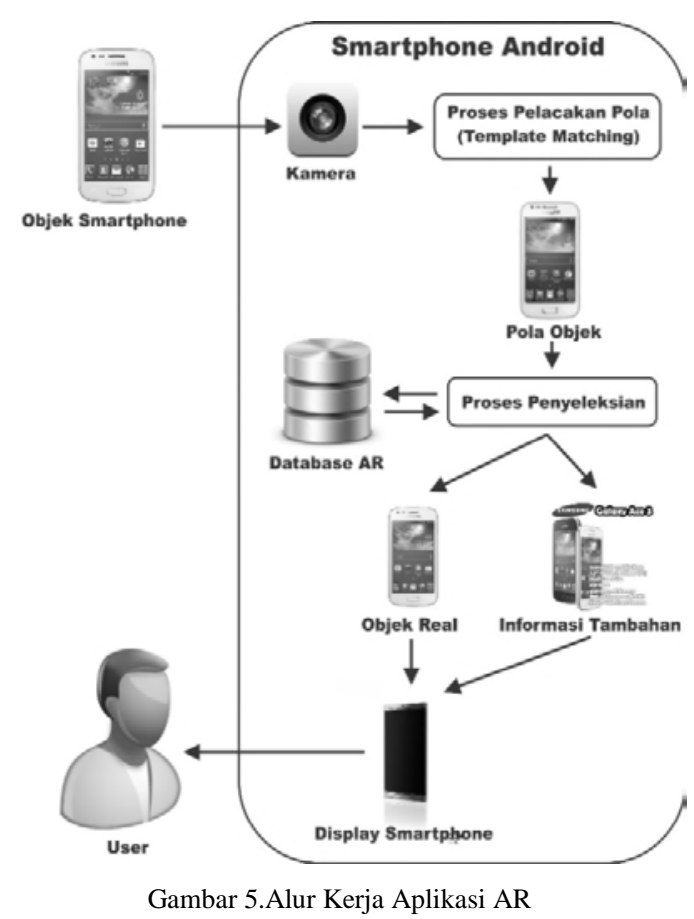

Informasi tambahan ditampilkan diatas objek markerless yang dapat dilihat oleh user pada display smartphone. Aplikasi Augmented Reality yang dirancang ditunjukkan pada Gambar 6.

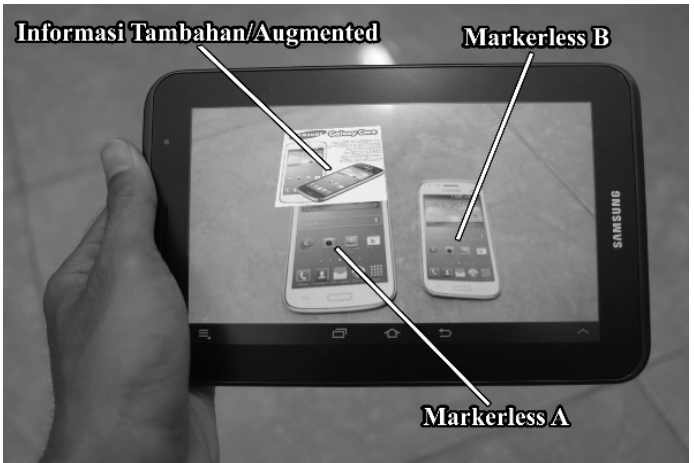

Gambar 6. Aplikasi Augmented Reality

\section{IV.HASIL}

Pengujian penelitian ini dilakukan dengan mengukur jarak jangkauan pengenalan markerless dari kamera smartphone. Jarak jangkauan pengenalan markerless diujikan dengan menggunakan 10 smartphone dari vendor yang berbeda-beda, dan memiliki spesifikasi yang berbeda-beda pula. Spesifikasi dari 10 smartphone tersebut diklasifikasikan berdasarkan besar pixel kamera, clock Processor, dan RAM. Hasil pengujian jarak pengenalan markerless pada smartphone terdapat pada Tabel 1. Proses pengujian dilakukan dengan menggunakan dua markerless yang berbeda ukuran. Markerless A memiliki ukuran dua kali dari ukuran markerless B. Markerless yang diujikan ditunjukkan pada Gambar 7.

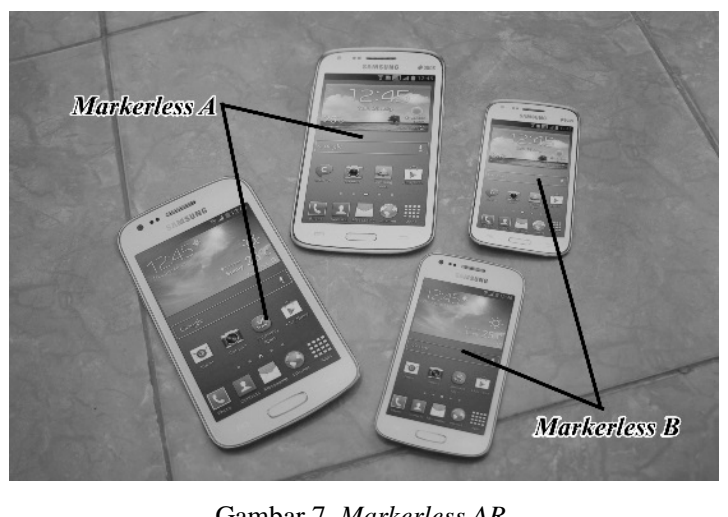

Gambar 7. Markerless AR

Tabel 1. Hasil Pengujian Jarak Jangkauan Pengenalan Markerless Pada Smartphone

\begin{tabular}{|c|c|c|c|c|c|c|c|}
\hline \multirow{2}{*}{ No } & \multirow{2}{*}{ KAMERA (MP) } & \multirow{2}{*}{ PROCESSOR } & \multirow{2}{*}{ RAM } & \multicolumn{2}{c|}{ MARKERLESS A } & \multicolumn{2}{c|}{ MARKERLESS B } \\
\cline { 4 - 8 } & & & MIN (cm) & MAX (cm) & MIN (cm) & MAX (cm) \\
\hline 1 & 3.15 & Single Core $1 \mathrm{GHz}$ & $768 \mathrm{MB}$ & 10 & 261 & 6 & 188 \\
\hline 2 & 5 & Single Core $1 \mathrm{GHz}$ & $512 \mathrm{MB}$ & 9 & 264 & 7 & 193 \\
\hline 3 & 5 & Singel Core $1,4 \mathrm{GHz}$ & $512 \mathrm{MB}$ & 9 & 254 & 7 & 178 \\
\hline 4 & 5 & Dual Core $1,2 \mathrm{GHz}$ & $768 \mathrm{MB}$ & 9 & 254 & 8 & 201 \\
\hline 5 & 8 & Single Core $1 \mathrm{GHz}$ & $512 \mathrm{MB}$ & 9 & 259 & 8 & 178 \\
\hline 6 & 8 & Single Core $1 \mathrm{GHz}$ & $512 \mathrm{MB}$ & 9 & 265 & 6 & 173 \\
\hline 7 & 8 & Single Core $1,4 \mathrm{GHz}$ & $512 \mathrm{MB}$ & 8 & 249 & 7 & 193 \\
\hline 8 & 8 & Dual Core $1,2 \mathrm{GHz}$ & $768 \mathrm{MB}$ & 9 & 252 & 9 & 183 \\
\hline 9 & 8 & Dual Core $1,2 \mathrm{GHz}$ & $1 \mathrm{~GB}$ & 7 & 234 & 5 & 158 \\
\hline 10 & 8 & Dual Core $1,4 \mathrm{GHz}$ & $1 \mathrm{~GB}$ & 9 & 264 & 6 & 193 \\
\hline
\end{tabular}


Pengujian jarak dilakukan untuk menentukan jarak jangkauan terdekat untuk kamera mengenali markerless (jarak minimum), dan jarak jangkauan terjauh untuk kamera mengenali markerless (jarak maximum). Jarak jangkauan terendah (minimum) yang baik adalah jarak jangkauan yang memiliki nilai terendah, karena user dapat mengetahui informasi tambahan objek tersebut pada jarak yang dekat. Sedangkan untuk jarak jangkauan terjauh (maximum) yang baik adalah jarak jangkauan yang memiliki nilai tertinggi, karena dapat membantu user untuk mendapatkan informasi tambahan objek tersebut pada jarak yang jauh.

Pengukuran jarak jangkauan pengenalan markerless dilakukan dengan meletakkan markerless tepat di depan perangkat Android, yang telah terpasang aplikasi Augmented Reality yang tealh dirancang dengan besar sudut $90^{\circ}$. Adapun posisi pengujian markerless terhadap perangkat Android ditunjukkan pada Gambar 8.

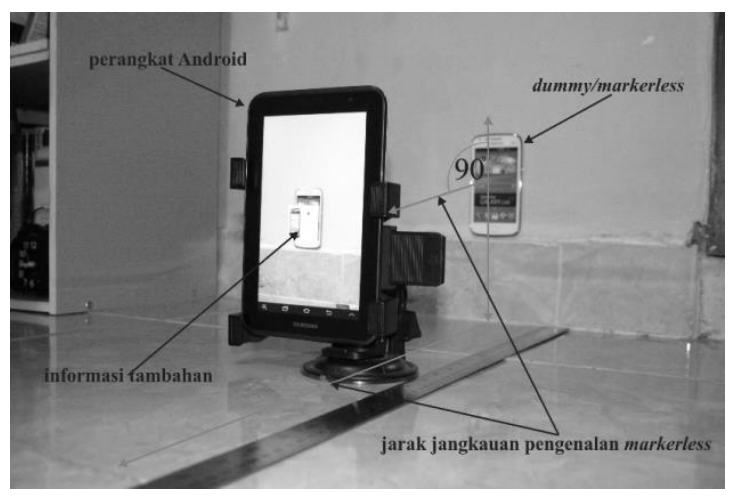

Gambar 8. Proses Pengujian Jarak Jangkauan Pengenalan Markerless

Proses pengujian dilakukan dengan mengukur jarak jangkauan dimana aplikasi $A R$ masih dapat melakukan pelacakan dan pengenalan markerless. Markerless diletakkan tegal lurus di depan perangkat Android. Adapun alat ukur yang digunakan berupa penggaris yang diletakkan di samping perangkat Android.
Nilai jarak jangkauan hasil pengujian yang didapatkan, kemudian dimasukkan ke dalam tabel untuk menentukan nilai ralat mutlak, ralat nisbi, keseksamaan, dan data pengukuran. Pencarian nilai ralat mutlak dimaksudkan untuk mengukur ketidakpastian akibat kesalahan pengukuran ataupun kesalahan kalibrasi.

Proses pelacakan titik-titik features terhadap resolusi kamera didapatkan dari hasil pembentukan matriks dan proses pemetaan titik-titik features pada matriks. Pembentukan kolom dan baris pembentuk matriks dilakukan pada fungsi void configureVideoBackground(). Kolom dan baris matriks didapatkan dari:

1. Resolusi kamera smartphone (lebar dan tinggi).

2. Resolusi layar smartphone (lebar dan tinggi).

Kemudian dari resolusi kamera dan layar smartphone dilakukan perhitungan pada formula (2), (3), (4), dan (5) sebagai berikut:

Kolom matriks:

$($ Data[0]) = tinggi kamera*(tinggi layar/ lebar kamera)

Baris matriks:

$($ Data[1] $)=$ tinggi layar

Jika kolom matriks $($ Data[0]) $<$ baris matriks (Data[1]), maka;

Kolom matriks baru:

$$
\left(\text { Data’}^{\prime}[0]\right)=\text { lebar layar }
$$

Baris matriks baru:

(Data'[1]) = lebar layar*(lebar kamera/ tinggi kamera)

Adapun kolom dan baris matriks, dan jumlah cell matriks dari smartphone yang diujikan pada penelitian ini terdapat pada Tabel 2. 
Tabel 2. Baris Dan Kolom Pembentuk Matrik Dari Smartphone

\begin{tabular}{|c|c|c|c|c|c|c|c|c|c|c|c|}
\hline \multirow{2}{*}{ No } & \multirow{2}{*}{$\begin{array}{l}Z_{1} \\
\text { 索 }\end{array}$} & \multirow{2}{*}{ Cam } & \multicolumn{2}{|c|}{ Video } & \multicolumn{2}{|c|}{ Screen } & \multirow{2}{*}{$\begin{array}{c}\text { DATA } \\
{[0]}\end{array}$} & \multirow{2}{*}{$\begin{array}{c}\text { DATA } \\
{[1]}\end{array}$} & \multirow{2}{*}{$\begin{array}{l}\text { DATA' } \\
{[0]}\end{array}$} & \multirow{2}{*}{$\begin{array}{c}\text { DATA' }^{\prime} \\
{[1]}\end{array}$} & \multirow{2}{*}{ Cell } \\
\hline & & & Height & Widht & Widht & Height & & & & & \\
\hline 1 & Non & 3.15 & 2048 & 1536 & 320 & 480 & 640 & 480 & 640 & 480 & 307,200 \\
\hline 2 & $\mathrm{AF}$ & 5 & 2592 & 1944 & 480 & 800 & 1066.67 & 800 & 1066.67 & 800 & 853,333 \\
\hline 3 & $\mathrm{AF}$ & 5 & 2592 & 1944 & 480 & 800 & 1066.67 & 800 & 1066.67 & 800 & 853,333 \\
\hline 4 & $\mathrm{AF}$ & 5 & 2592 & 1944 & 480 & 800 & 1066.67 & 800 & 1066.67 & 800 & 853,333 \\
\hline 5 & Non & 8 & 2596 & 1948 & 480 & 800 & 1066.12 & 800 & 1066.12 & 800 & 852,895 \\
\hline 6 & $\mathrm{AF}$ & 8 & 3264 & 2448 & 480 & 854 & 1138.67 & 854 & 1138.67 & 854 & 972,421 \\
\hline 7 & $\mathrm{AF}$ & 8 & 3264 & 2448 & 480 & 854 & 1138.67 & 854 & 1138.67 & 854 & 972,421 \\
\hline 8 & $\mathrm{AF}$ & 8 & 3200 & 2400 & 540 & 960 & 1280 & 960 & 1280 & 960 & $1,228,800$ \\
\hline 9 & $\mathrm{AF}$ & 8 & 3264 & 2448 & 540 & 960 & 1280 & 960 & 1280 & 960 & $1,228,800$ \\
\hline 10 & $\mathrm{AF}$ & 8 & 3264 & 2448 & 800 & 1280 & 1706.67 & 1280 & 1706.67 & 1280 & $2,184,533$ \\
\hline
\end{tabular}

Pemetaan matriks yang dibentuk dan pemetaan featuresmarkerless ditunjukkan pada Gambar 9.

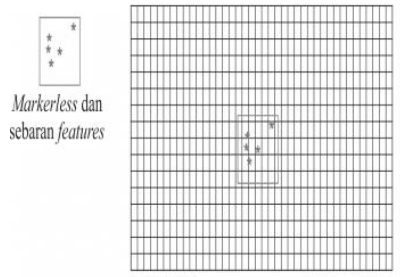

(a)

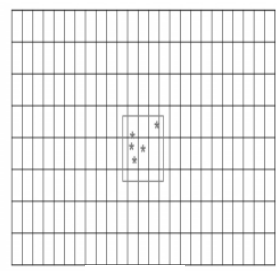

(c)

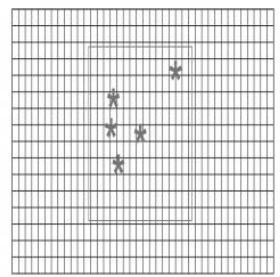

(b)

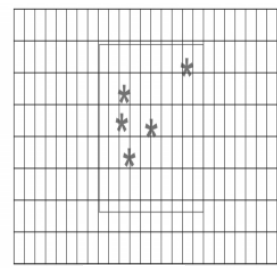

(d)
Gambar 8. Pemetaan Titik Features Pada Matriks Yang Dibentuk

Pada Gambar 8 ditunjukkan bahwa:

1. Gambar 8.a, penanda pada posisi jauh, terhadap matriks dengan kolom dan baris yang besar (rapat), maka titik-titik features dapat dipetakan satu feature pada satu cell.

2. Gambar 8.b, penanda pada posisi dekat terhadap matriks dengan kolom dan baris yang besar (rapat), maka titik-titik features dapat dipetakan satu feature pada satu cell.

3. Gambar 8.c, penanda pada posisi jauh terhadap matriks dengan kolom dan baris yang sedikit (renggang), maka titik-titik features memungkinkan terdapat lebih dari satu feature pada satu cell.

4. Gambar 8.d, penanda pada posisi dekat terhadap matriks dengan kolom dan baris sedikit (renggang), maka titik-titik features dapat dipetakan satu feature pada satu cell.

Analisis hasil pengujian kebutuhan (requirements testing) sistem terhadap resolusi kamera smartphone; smartphone dengan resolusi kamera rendah membentuk pemetaan gambar dengan ukuran kolom dan lebar matriks yang lebih kecil dibandingkan dengan pemetaan gambar oleh smartphone dengan resolusi kamera tinggi. Hal ini menyebabkan pada smartphone dengan resolusi kamera rendah dapat memetakan gambar untuk melacak seluruh features dari markerless pada jarak minimum, dan melakukan pelacakan features markerless tepat pada masing-masing kolom dan baris matriks. Sedangkan, pemetaan gambar dalam matriks berukuran besar memudahkan untuk pelacakan markerless pada jarak jangkauan maksimum, karena pelacakan features lebih rapat dan dapat dipetakan pada setiap cell matriks. 
Tabel 3 menunjukkan jarak jangkauan pengenalan markerless berdasarkan besar pixel kamera. Hasil pengujian menunjukkan bahwa kamera dengan pixel yang rendah $(3,15 \mathrm{MP} \rightarrow$ $261 \mathrm{~cm}$ dan $5 \mathrm{MP} \rightarrow 190,7 \mathrm{~cm})$ dapat mengenali markerless untuk jarak yang jauh dibandingkan kamera dengan pixel tinggi (8MP). Sedangkan, kamera dengan pixel yang tinggi $(8 \mathrm{MP} \rightarrow 8,5 \mathrm{~cm}$ dan $6,8 \mathrm{~cm})$ dapat mengenali markerless untuk jarak yang dekat dibandingkan kamera dengan pixel rendah (3,15MP dan 5MP).

Tabel 3. Pengujian Jarak Jangkauan Pengenalan Markerless Berdasarkan Besar Pixel Kamera

\begin{tabular}{|l|l|l|l|l|}
\hline \multirow{2}{*}{ KAMERA } & \multicolumn{2}{|c|}{ MARKERLESS } & \multicolumn{2}{c|}{ MARKERLESS } \\
\cline { 2 - 5 } & MIN & MAX & MIN & MAX \\
\hline 3.15 MP & 10 & 261 & 6 & 188 \\
\hline 5 MP & 9 & 257,3 & 7,3 & 190,7 \\
\hline 8 MP & 8,5 & 253,8 & 6,8 & 179,7 \\
\hline
\end{tabular}

Pada Tabel 4, pengujian jarak jangkauan pengenalan markerless berdasarkan nilai clock Processor, menunjukkan bahwa clock Processor yang tinggi (dual core $1,2 \mathrm{GHz} \rightarrow 8,3 \mathrm{~cm}$, dan dual core $1,4 \mathrm{GHz} \rightarrow 6 \mathrm{~cm}$ ) dapat mengenali markerless untuk jarak yang dekat dibandingkan dengan clock Processor rendah (single core $1 \mathrm{GHz}$ dan single core $1,2 \mathrm{GHz})$. Sedangkan untuk jarak jangkauan pengenalan yang jauh, Processor dengan clock yang tinggi (dual core $1,4 \mathrm{GHz} \rightarrow 264 \mathrm{~cm}$ dan 193cm) lebih jauh dibandingkan Processor dengan clock rendah (single core $1 \mathrm{GHz}$, single core 1,2GHz, dualcore 1,2GHz).

Tabel 4. Pengujian Jarak Jangkauan Pengenalan Markerless Berdasarkan Processor

\begin{tabular}{|l|l|l|l|l|}
\hline \multirow{2}{*}{$\begin{array}{c}\text { PROCESSOR } \\
\text { (GHz) }\end{array}$} & \multicolumn{2}{|c|}{ MARKERLESS } & \multicolumn{2}{c|}{ MARKERLESS } \\
\cline { 2 - 5 } & \multicolumn{1}{|c|}{ MIN } & MAX & \multicolumn{1}{c|}{ MIN } & MAX \\
\hline Single Core 1 & 9,25 & 262,3 & 6,8 & 183 \\
\hline $\begin{array}{l}\text { Single Core } \\
1,2\end{array}$ & 8,5 & 251,5 & 7 & 185,5 \\
\hline Dual Core 1,2 & 8,3 & 246,7 & 7,3 & 180,7 \\
\hline Dual Core 1,4 & 9 & 264 & 6 & 193 \\
\hline
\end{tabular}

Pada Tabel 5, pengujian jarak jangkauan pengenalan markerless berdasarkan besar RAM, menunjukkan bahwa RAM yang tinggi (1GB $\rightarrow$ $8 \mathrm{~cm}$ dan 5,5cm) dapat mengenali markerless pada jarak yang dekat dibandingkan RAM yang rendah (512MB dan 768MB), sedangkan RAM yang rendah $(512 \mathrm{MB} \rightarrow 258,2 \mathrm{~cm}, 768 \mathrm{MB} \rightarrow 190,7 \mathrm{~cm})$ dapat mengenali markerless untuk jarak yang jauh dibandingkan dengan RAM yang tinggi (1GB)

Tabel 5. Pengujian Jarak Jangkauan Pengenalan Markerless Berdasarkan RAM

\begin{tabular}{|l|l|l|l|l|}
\hline \multirow{2}{*}{ RAM } & \multicolumn{2}{|c|}{ MARKERLESS } & \multicolumn{2}{c|}{ MARKERLESS } \\
& \multicolumn{2}{|c|}{ A } & \multicolumn{2}{c|}{ B } \\
\cline { 2 - 5 } & MIN & MAX & \multicolumn{1}{c|}{ MIN } & MAX \\
\hline $512 \mathrm{MB}$ & 8,8 & 258,2 & 7 & 183 \\
\hline $768 \mathrm{MB}$ & 9,3 & 255,7 & 7,7 & 190,7 \\
\hline $1 \mathrm{~GB}$ & 8 & 249 & 5,5 & 175,5 \\
\hline
\end{tabular}

\section{KESIMPULAN}

Penelitian ini melakukan evaluasi metode template matching pada pengenalan markerless Augmented Reality. Evaluasi tersebut meliputi jarak jangkauan pengenalan markerless terhadap besar pixel kamera, clock Processor, RAM, dari beberapa smartphone yang berbeda-beda. Jarak jangkauan pengenalan markerless terdekat (minimum) dapat dilakukan dengan baik pada smartphone denganbesar pixel kamera tinggi, Processor clock tinggi dan RAM yang tinggi. Sedangkan, untuk mengenali penanda terjauh (maximum) dapat dilakukan dengan baik pada besar pixel kamera rendah, clock Processor tinggi, dan RAM yang rendah.

\section{REFERENS}

[1] M.T., M.R., and S.P, "Review Article: An Overview of Template Matching Techique In Image Processing," Reaserch Journal of Applied Sciences Engineering and TEchnology 4(24):5469-5473 2012, 2012.

[2] R. Laganiere, OpenCV 2 Computer Vision Application Programming Cookbook vol. 1. BIRMINGHAMMUMBAI: PACKT Publishing Ltd., 2011. 
[3] G. Klein, "Visual Tracking For Augmented Reality," Degree of Doctor of Philosophy, Department of Engineering, University of Cambridge, 2006.

[4] D. Stricker and G. Bleser, "From Interactive to Adaptive Augmented Reality," in Ubiquitous Virtual Reality (ISUVR), 2012 International Symposium on, 2012, pp. 1821.

[5] C. R. Warrington, "Markerless Augmented Reality for Panoramic Sequences," Postgraduate Program, School of Information Technology and Engineering, Faculty of Engineering, University of Ottawa, Canada, 2007.

[6] M. Hincaoie., A. Caponio., H. Rios., and E. G. Mendivil, "An Introduction to Augmented Reality with Applications in Aeronautical Maintenance," in ICTON 2011, 2012.

[7] D. L. Baggio, D. M. Escriva, N. Mahmood, R. Shilkrot, S. Emami, K. Levgen, and J. Saragih, Mastering OpenCV with Practical Computer Vision Projects: PACKT Publishing, 2011. 